\title{
TIMSS 2011 Science Assessment Results: A Review of Ghana's Performance
}

\author{
Isaac Buabeng $^{1,2, *}$, Kofi Acheaw Owusu ${ }^{1,2} \&$ Forster Danso Ntow ${ }^{1,3}$ \\ ${ }^{1}$ University of Cape Coast, Ghana \\ ${ }^{2}$ University of Canterbury, New Zealand \\ ${ }^{3}$ University of Minnesota, USA \\ *Corresponding author: College of Education, University of Canterbury, Christchurch 8041, New Zealand. Tel: \\ 64-223-907-133. E-mail: ibuabeng@ucc.edu.gh/isaac.buabeng@pg.canterbury.ac.nz
}

Received: May 9, $2014 \quad$ Accepted: June 16, $2014 \quad$ Online Published: July 3, 2014

doi:10.5430/jct.v3n2p1 URL: http://dx.doi.org/10.5430/jct.v3n2p1

\begin{abstract}
This paper reviews Ghana’s performance in the TIMSS 2011 survey in comparison with other African and some high performing countries which participated in the TIMSS assessment. Students' achievement in the science content areas assessed were summarized and teacher preparation constructs of teachers of the students who took part in the assessment explored with the aim of finding any possible linkage between teacher preparation and students achievement. Two set of reviews were done. First, results on the eighth grade (JHS 2) science content achievement in biology, chemistry, physics, and earth science for Ghana, Morocco and Tunisia were compared. The second review compared how Ghana prepares her teachers to Finland and Singapore who were among the first five performing countries on the TIMSS 2011 assessment. Some mismatch was identified in terms of teacher preparation and students' achievement in the case of Ghana. Ghanaian teachers scored relatively high on most of the constructs that were measured by the TIMSS report under teacher preparation but these were not reflected in the students' achievement. In view of this, it is recommended that other indicators such as classroom instruction, resources for teaching science, and school climate are investigated with the aim of finding any other underlying factors that could account for the mismatch between Ghanaian students' achievement on the TIMSS science assessment and teachers' preparation.
\end{abstract}

Keywords: TIMSS 2011; Ghana; students’ achievement; teacher preparation

\section{Introduction}

Trends in International Mathematics and Science Study (TIMSS) started in 1995 and are administered on a four-year cycle; hence, the 2011 assessment served as the fifth in the series. The TIMSS 2011 report also provided an updated picture of performance for the participating countries. This paper summarizes Ghana's performance on the TIMSS test items as well as some teacher preparation constructs as measured on the TIMSS 2011 assessment instrument in comparison with other African countries that participated in the assessment and offers some recommendations for improving quality of basic education in Ghana. We used TIMSS 2011 data as convenience (Akiba, LeTendre, \& Scribner, 2007) to compare Ghanaian students’ performance in science against the quality of teachers who teach grade eight (JHS 2) science.

Over the years, the TIMSS science assessment has been organized around two dimensions - content dimension and cognitive dimension. The TIMSS 2011 science assessment was no exception. The content dimension specifies the subject matter or content domains to be assessed whereas the cognitive dimension specifies the thinking processes that students are likely to use as they engage with the content. Each item in the science assessment is associated with one content domain and one cognitive domain; providing for both content-based and cognitive-oriented perspectives on student achievement in science (International Association for the Evaluation of Educational Achievement [IEA], 2012). 
The TIMSS assessment is usually organised for two categories of students, grade four (ages 9-10 or Primary 4) and grade eight (ages 12-13 or JHS 2) but countries like UK, Malta and New Zealand whose students start school at a young age are normally assessed at the fifth grade. Moreover, TIMSS International Study Centre encourages countries that believe the assessment is too difficult for fourth grade students to give the TIMSS fourth grade assessment at the sixth grade. Similar provision is made for the eighth grade TIMSS assessment so that countries can participate at the ninth grade if need be.

The fourth grade science assessment covers three content domains -life science, physical science, and earth science. At the eighth grade however, four content domains are covered. These are biology, chemistry, physics, and earth science. Nonetheless, the same three cognitive domains (knowing, applying, and reasoning) are used at both fourth and eighth grades. Students' knowledge of science facts, procedures, and concepts are assessed under knowing whereas applying focuses on the students' ability to apply knowledge and conceptual understanding in a science problem situation. Items measuring reasoning, on the other hand, go beyond the solution of routine science problems to encompass unfamiliar situations, complex contexts, and multi-step problems (IEA, 2012). The TIMSS 2011 results for the participating African countries are presented and discussed below.

\section{Students’ Achievement in Science Content Domains}

Results on the eighth grade science content in biology, chemistry, physics, and earth science are shown in Table 1. Three African countries-Tunisia, Morocco and Ghana- participated at the eighth grade. Botswana and South Africa, however, participated at the ninth grade as indicated in Table 1. Ninth grade participants are students from countries which believe the content on the TIMSS assessment are adequately covered in grade nine and not grade eight.

Table 1. Eighth Grade Ranking and Achievement in Science Content Domains

\begin{tabular}{|c|c|c|c|c|c|c|}
\hline \multirow[t]{2}{*}{ Ranking } & \multirow[t]{2}{*}{ Country } & \multirow{2}{*}{$\begin{array}{l}\text { Overall } \\
\text { average } \\
\text { score }\end{array}$} & \multicolumn{4}{|c|}{ Average scale score } \\
\hline & & & Biology & Chemistry & Physics & Earth Science \\
\hline 29 & Tunisia & $439(2.5)$ & $449(3.0)$ & 434 (3.3) & $436(2.6)$ & $414(3.6)$ \\
\hline 41 & Morocco & $376(2.2)$ & $378(3.0)$ & $374(2.2)$ & $349(2.5)$ & $377(3.3)$ \\
\hline \multirow[t]{3}{*}{42} & Ghana & $306(5.2)$ & $290(6.2)$ & 331 (5.9) & $292(5.9)$ & $265(6.5)$ \\
\hline & *Botswana & 404 (3.6) & 401 (3.9) & $403(3.6)$ & 417 (3.6) & $384(4.2)$ \\
\hline & *S. Africa & 332 (3.7) & 318 (3.8) & 336 (3.8) & 351 (3.7) & $294(3.8)$ \\
\hline
\end{tabular}

*Ninth grade participants. Parentheses ( ) are standard errors.

Among the 42 participating countries worldwide, Tunisia was ranked 29th with an overall average score of 439. Morocco and Ghana occupied the last two positions on the international table respectively. In addition to occupying the last position on the international table, Ghana's overall average performance was also significantly lower than the other two countries. In all the four science content areas that were assessed, Tunisia and Morocco performed better than Ghana. Inferences from Table 2 indicate that Tunisia had the highest average achievement, and had higher achievement in all the four areas followed by Morocco with Ghana obtaining the least achievement across board. Whereas Tunisia was close to the TIMSS scale counterpoint achievement of 500 (i.e. with only 61 points less), Ghana was 194 points less to the TIMSS scale counterpoint. Further analysis revealed that Ghana performed poorly in Biology, Physics and Earth Science with their respective average scores below 300. The TIMSS 2011 report stressed that among the eighth grade participating countries "only Ghana had many low performing students, with a percentage of students with achievement too low for estimation between 15 and 25 percent (IEA, 2012, p. 47).

Ghana's low performance also meant that most of the students who participated in the TIMSS 2011 assessment were classified as performing below the Low International benchmark. TIMSS reports achievement at four points along the scale as international benchmarks: Advanced International Benchmark (625), High International Benchmark (550), Intermediate International Benchmark (475), and Low International Benchmark (400), with the scores on the test ranging from 0-1000. The percentage of eighth grade students from the participating African countries reaching the international benchmarks of science achievement relative to the overall average score is shown in Tunisia was the only country that had $30 \%$ of her eighth grade students attaining Intermediate Benchmark with the majority of students (72\%) attaining the Low International Benchmark. Ghana had 6\% and 22\% of her eight grade students reaching Intermediate and Low Benchmarks respectively. Relative to the overall average score, only Tunisia (with an 
average score of 439) attained the Low International Benchmark (400). Morocco and Ghana did not attain any of the benchmarks. Botswana and South Africa who assessed their students at the ninth grade had average achievement score of 404 and 332 respectively. Botswana students' average was just above Low International Benchmark (400) whereas South Africa's students' average was a little below the Low International Benchmark (400) for eighth grade students.

Tunisia was the only country that had $30 \%$ of her eighth grade students attaining Intermediate Benchmark with the majority of students (72\%) attaining the Low International Benchmark. Ghana had 6\% and 22\% of her eight grade students reaching Intermediate and Low Benchmarks respectively. Relative to the overall average score, only Tunisia (with an average score of 439) attained the Low International Benchmark (400). Morocco and Ghana did not attain any of the benchmarks. Botswana and South Africa who assessed their students at the ninth grade had average achievement score of 404 and 332 respectively. Botswana students' average was just above Low International Benchmark (400) whereas South Africa's students' average was a little below the Low International Benchmark (400) for eighth grade students.

Table 2. Percentage of Students Reaching TIMSS International Benchmarks

\begin{tabular}{|c|c|c|c|c|c|}
\hline \multirow[b]{2}{*}{ Country } & \multirow[b]{2}{*}{$\begin{array}{l}\text { Overall } \\
\text { average } \\
\text { score }\end{array}$} & \multicolumn{4}{|c|}{ International Benchmarks } \\
\hline & & $\begin{array}{l}\text { Advanced } \\
\text { Benchmark } \\
(625)\end{array}$ & $\begin{array}{l}\text { High } \\
\text { Benchmark } \\
(550)\end{array}$ & $\begin{array}{l}\text { Intermediate } \\
\text { Benchmark (475) }\end{array}$ & $\begin{array}{l}\text { Low } \\
\text { Benchmark } \\
(400)\end{array}$ \\
\hline Tunisia & $439(2.5)$ & $0(0.1)$ & $5(0.7)$ & $30(1.4)$ & $72(1.3)$ \\
\hline Morocco & $376(2.2)$ & $0(0.0)$ & $2(0.2)$ & $13(0.7)$ & $39(1.0)$ \\
\hline Ghana & $306(5.2)$ & $0(0.1)$ & $1(0.2)$ & $6(0.8)$ & $22(1.8)$ \\
\hline *Botswana & $406(3.6)$ & $1(0.2)$ & $6(0.6)$ & $26(1.4)$ & $55(1.4)$ \\
\hline *South Africa & 332 (3.7) & $1(0.2)$ & $4(0.4)$ & $11(0.8)$ & $25(1.1)$ \\
\hline
\end{tabular}

*Ninth grade participating countries. Parentheses ( ) are standard errors.

South Africa was also reported to have had many very low performing ninth grade students, with the percentage of students with achievement too low for estimation between 15 percent and 25 percent.

\section{Students' Achievement in Science Cognitive Domains}

This section presents and discusses the average achievement at eighth grade in the cognitive domains of knowing, applying, and reasoning for Ghana, Morocco and Tunisia relative to their overall science average scores. Similar to the content domains, eighth grade students from Tunisia performed better in all the cognitive domains than Morocco and Ghana as shown in Table 3. Morocco also performed relatively well than Ghana in the three cognitive domains. In all, Tunisia and Ghana showed relative strength in reasoning with Morocco showing relative strength in applying. Ghana had a weakness in both knowing and applying.

Table 3. 8th Grade Achievement in Science Cognitive Domains

\begin{tabular}{lllll}
\hline Country & Overall average & \multicolumn{3}{c}{ Average scale score } \\
\cline { 3 - 5 } & score & Knowing & Applying & Reasoning \\
\hline Tunisia & $439(2.5)$ & $424(2.3)$ & $437(2.2)$ & $446(2.7)$ \\
Morocco & $376(2.2)$ & $363(2.7)$ & $381(1.9)$ & $366(2.3)$ \\
Ghana & $306(5.2)$ & $292(6.1)$ & $295(6.3)$ & $315(4.9)$ \\
\hline
\end{tabular}

Parentheses ( ) are standard errors

\section{Trends in Science Achievement}

This section sought to review the changes in overall average science achievement for Ghana, Morocco and Tunisia with their comparable data from previous TIMSS assessments. The trend in science achievement at the eighth grade 
is shown in Figure 1 for only Tunisia and Ghana since Morocco has no comparable data at the eighth grade from previous TIMSS assessments that can be compared to TIMSS 2011.

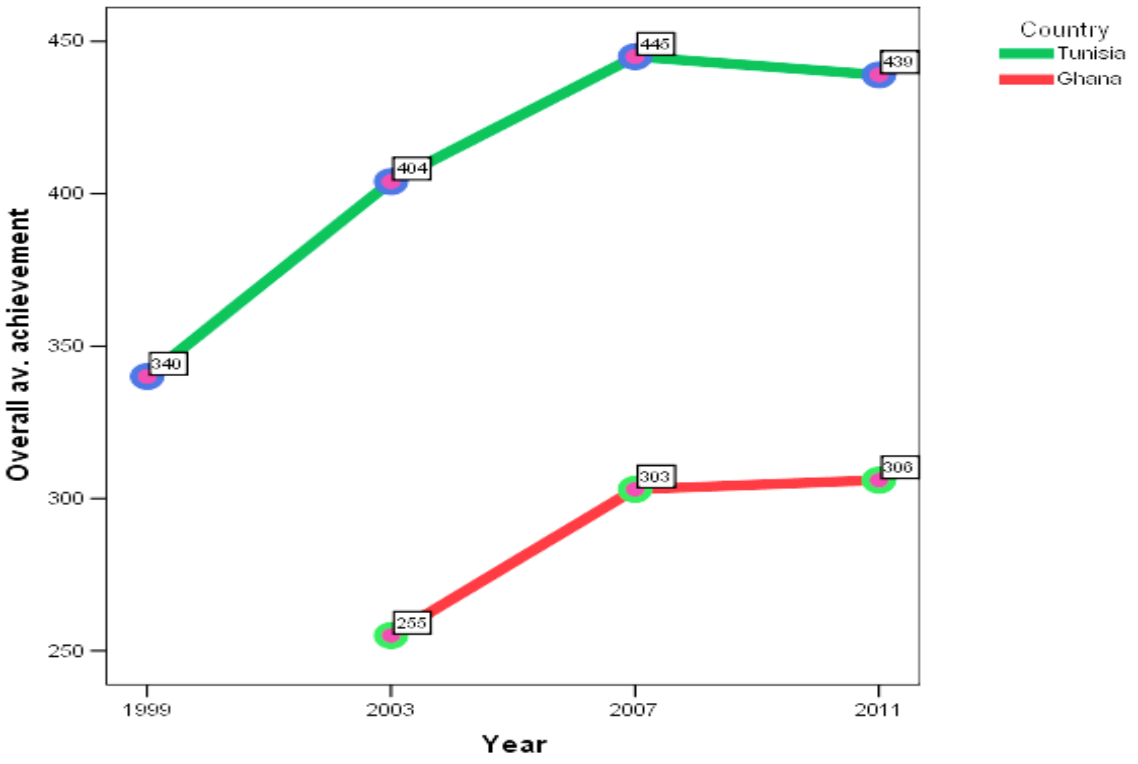

Figure 1. $8^{\text {th }}$ Grade Trends in Science Achievement

Ghana showed an increase in average achievement of 3 and 51 points respectively, i.e. when previous assessment results of 2007 and 2003 are compared with 2011 results. Tunisia also showed a tremendous increase in average achievement from 1999 to 2007. However, there was a decrease (6 points) in average achievement in 2011.

Comparatively, Ghana's achievement, although has shown some improvement, has been consistently poor relative to the TIMSS benchmarks since her participation in 2003. Although Ghana's performance in 2007 was a significant improvement over that of 2003, there was no significant improvement of the 2011 results compared to that of 2007. Though there was slight improvement in 2011, Ghana's achievement was the lowest in Africa and the world.

From the summary of results shown so far, Ghana's performance relative to other African countries gives some indications that Ghanaian grade eight students are not achieving at the levels expected when compared to students at comparable grade levels. As such, it will be prudent to investigate some underlying cause(s) of eight grade students' underperformance in science.

\section{Science Teachers’ Formal Education in Ghana}

Even though we have presented Ghana’s performance against other African countries that have been participating in TIMSS assessment, we believe that a lot can be learnt, from the top achieving countries, for example the top five countries - Singapore, Chinese Taipei, Korea Rep, Japan and Finland which had average achievement above the High International Benchmark of 550. These countries performed far better than Ghana and the rest of the African countries that participated in the study hence it would not be out of place to look within and outside the African continent to examine practices that are making these countries out-perform their counterparts in this international assessment. For Ghana to improve its performance in future TIMSS assessments, we have discussed one of the contributing factors - teacher preparation and have discussed Ghana's performance in the light of two high achieving countries (Singapore and Finland) which can serve as a guide to any future policies.

\section{Quality Teacher Preparation}

Trends in International Mathematics and Science Study (TIMSS) report indicated how relevant a well prepared teaching force is to any educational system. This view is shared by Darling-Hammond (2000) who reiterated the positive and strong correlation between teacher preparation and students' achievement. In 1996, in the United States (US), the National Research Council's National Science Education Standards put forward five assumptions about science teaching, including the belief that, "What students learn is greatly influenced by how they are taught" (National Research Council, 1996, p. 28). Moreover, in the same year, the standards called for a pedagogical shift 
from a teacher-centred to a student-centred instructional paradigm. It was further held that a more student-centred approach to learning engages students in socially interactive scientific inquiry and facilitates lifelong learning. This, therefore, suggests that students cannot achieve high levels of performance in the absence of qualified, skilled, talented and dedicated teachers. Improving teacher quality has since been a major focus of America's educational reforms. The country's 2006 annual report (US Department of Education, 2006, p. iii) describes the country's position on teacher quality as follows:

In order to strengthen our nation's competitiveness in the global market places, as well as our security at home, we must be certain that teacher proficiency in mathematics, science, technology and foreign languages is sufficient to enable America's students to achieve at grade level and above these subjects.

Research findings confirm that teacher quality looks to be the most essential factor influencing student achievement (Darling-Hammond, 2000; Darling-Hammond, Berry, \& Thoreson, 2001; Goldhaber \& Anthony, 2003). Most often, academic preparation of teachers, type of certificate, and years of teaching experience, among others, are taken as indicators of teacher quality. Teachers who have acquired sufficient academic preparation are seen to be competent in subject matter content and pedagogical skills enabling them to be effective in classrooms and produce larger student achievement gains (Darling-Hammond, 2000; McDermott \& Shaffer, 2000; Orleans, 2007).

Most of the research on student learning has examined the relationship between measures of student performance (most commonly standardized test scores) and readily measurable teacher characteristics such as qualifications, teaching experience, and indicators of academic ability or subject-matter knowledge (Darling-Hammond, 2000; Hendriks, Luyten, Scheerens, Sleegers, \& Steen, 2010; Scheerens, 2009). Such research generally indicates that there is a positive relationship between these measured teacher characteristics and student performance. It must be pointed out that there are many important aspects of teacher quality that are not captured by the commonly used indicators (e.g. qualifications and experience). The teacher characteristics that are harder to measure, but which can be vital to student learning include the ability to convey ideas in clear and convincing ways; to create effective learning environments for different types of students; to foster productive teacher-student relationships; to be enthusiastic and creative; and to work effectively with colleagues and parents (Akiba et al., 2007). However difficult they may be, constant evaluation of teachers' competencies and qualification are required to ensure excellent delivery of instruction especially in the sciences. The TIMSS report under review provides rich information on science and mathematics teachers' preparation of the participating countries which includes Ghana. The areas under teacher preparations that were considered in the TIMSS report include are: science teachers' formal education; teachers majoring in education and science; teachers' years of experience; teachers' professional development within the last two years; teachers' preparation to teach the TIMSS science topics; teachers' confidence in teaching science; and teachers' career satisfaction.

In Ghana, teachers are categorized into professional and non-professional teachers. Professional teachers are those with certificates in education from an accredited higher educational institution whereas the non-professional teachers are grouped into: persons with high school certificate; persons with diploma from polytechnics and non-teaching tertiary institutions; and university graduates without certificate in education (Ministry of Education, 2012). Teachers who teach in Ghanaian JHS where grade eight falls are predominantly products of colleges of education (previously, teacher training colleges) which are accredited educational institutions. Those who choose to teach at this level enter these colleges of education after their high school education. Upon gaining admission, these pre-service teachers undergo a three-year education program leading to the award of a Diploma in Basic Education. The three year program is divided into two years of course work and one year of practicum with trainees engaged in "supervised" internship in schools. The Diploma in Basic Education is supposed to be the minimum qualification for basic school teachers. However, for one reason or the other, persons with high school certificates are also recruited to teach at the JHS level.

Since teachers have been identified as indispensable in the quest for quality education, the TIMSS 2011 report, investigated any possible link between teacher preparation and students' achievement. The results showed that high performing countries on the TIMSS science assessment had science teachers with higher qualifications teaching science in their schools. Ghana's science teachers' highest qualifications are compared with some participating countries in Table 4 below. 
Table 4. Percentage Distribution of Science Teachers’ Highest Qualification

\begin{tabular}{lcccc}
\hline Country & $\begin{array}{l}\text { \%Completed } \\
\text { postgraduate } \\
\text { University } \\
\text { degree }\end{array}$ & $\begin{array}{l}\text { \%Completed Bachelor's } \\
\text { degree or equivalent but } \\
\text { not a postgraduate degree }\end{array}$ & $\begin{array}{l}\text { \%Completed } \\
\text { Post-secondary } \\
\text { education but } \\
\text { not a bachelor's } \\
\text { degree }\end{array}$ & $\begin{array}{l}\text { \%No further than } \\
\text { Upper-secondary } \\
\text { education }\end{array}$ \\
\hline Ghana & 2 & 18 & 65 & 15 \\
Tunisia & 1 & 83 & 0 & 0 \\
Morocco & 4 & 39 & 0 & 57 \\
Finland & 89 & 10 & 3 & 0 \\
Singapore & 13 & 84 & 0 & 16 \\
\hline
\end{tabular}

Ghana had $65 \%$ of its $8^{\text {th }}$ grade (JHS 2) teachers holding post-secondary education qualification which is not equivalent to a bachelor's degree. Tunisia had $83 \%$ of her teachers having a bachelor's degree; Finland had $89 \%$ of the science teachers holding a postgraduate university degree. With the exception of Morocco, Ghana had the highest proportion (15\%) of teachers who had no further qualifications after upper secondary school education teaching in the $8^{\text {th }}$ grade level.

\section{Teachers’ Professional Development}

The TIMSS report sought to find out how much professional development teachers had two years prior to the commencement of the research. Science Content, Science Pedagogy/Instruction, Science Curriculum, Integrating Information Technology into Science, Improving Students' Critical Thinking or Inquiry Skills and Science Assessment were the areas of professional development the TIMSS 2011 report surveyed teachers on. The percentage of students whose teachers had professional development in these areas in Ghana is compared with those of Tunisia, Morocco, Singapore and Finland in Table 5

Table 5. Percentage of Students Whose Teachers Participated in Various Professional Developments as Captured by TIMSS 2011

\begin{tabular}{|c|c|c|c|c|c|c|}
\hline Countries & $\begin{array}{l}\text { Science } \\
\text { Content }\end{array}$ & $\begin{array}{l}\text { Science } \\
\text { Pedagogy/ } \\
\text { Instruction }\end{array}$ & $\begin{array}{l}\text { Science } \\
\text { Curriculum }\end{array}$ & $\begin{array}{l}\text { Integrating } \\
\text { Information } \\
\text { Technology } \\
\text { into Science }\end{array}$ & $\begin{array}{l}\text { Improving } \\
\text { Students } \\
\text { Critical } \\
\text { Thinking or } \\
\text { Inquiry } \\
\text { Skills }\end{array}$ & $\begin{array}{l}\text { Science } \\
\text { Assessment }\end{array}$ \\
\hline Ghana & 63 & 53 & 54 & 32 & 53 & 70 \\
\hline Tunisia & 66 & 78 & 60 & 59 & 36 & 63 \\
\hline Morocco & 49 & 64 & 56 & 50 & 17 & 47 \\
\hline Finland & 25 & 23 & 6 & 29 & 6 & 6 \\
\hline Singapore & 71 & 88 & 67 & 70 & 74 & 65 \\
\hline $\begin{array}{l}\text { International } \\
\text { average }\end{array}$ & 55 & 58 & 53 & 49 & 43 & 48 \\
\hline
\end{tabular}

Grade eight students in Ghana seemed to have teachers who had participated in more professional development in areas of Science Content, Science Curriculum, Improving Students' Critical thinking or Inquiry Skills and Science Assessment as the percentages of students whose teachers had participated in professional development in these areas were higher than the international averages as reported by TIMSS 2011. Ghana only fell short of the international average in Science Pedagogy/Instruction and Integrating Information Technology into Science. What is the implication?

\section{Teachers' Preparedness to Teach the TIMSS Science Topics}

The TIMSS 2011 report also assessed how prepared teachers of participating students thought they were in teaching the content areas that were covered by the assessment tools. They aimed at finding out whether these teachers felt 'very well prepared', 'somewhat prepared' or 'not well prepared' to teach the various content topics that were assessed by TIMSS. For the grade 8 which Ghana participated, the report presented the percentages of students 
whose teachers felt they were "very well prepared" to teach the content areas of the TIMSS tests. The report categorized the items into Biology, Chemistry, Physics, and Earth Science and then combined all the items to form an Overall Science subsection. Table 6 presents the data of Ghana and selected countries in Africa and around the world.

Table 6. Grade 8 Teachers Who Felt "Very Well Prepared" to Teach TIMSS Science Topics as Percentage of Their Students

\begin{tabular}{lccccc}
\hline Countries & $\begin{array}{c}\text { Overall } \\
\text { Science }\end{array}$ & $\begin{array}{c}\text { Biology } \\
\text { (7 Topics) }\end{array}$ & $\begin{array}{c}\text { Chemistry } \\
\text { (4 Topics) }\end{array}$ & $\begin{array}{c}\text { Physics } \\
\text { (5 Topics) }\end{array}$ & $\begin{array}{c}\text { Earth Science } \\
\text { (4 Topics) }\end{array}$ \\
\hline Ghana & 81 & 88 & 90 & 86 & 51 \\
Tunisia & 61 & 80 & -- & -- & 26 \\
Morocco & 75 & 82 & 88 & 81 & 45 \\
Finland & 81 & 84 & 86 & 86 & 62 \\
Singapore & 57 & 60 & 80 & 75 & 6 \\
$\begin{array}{l}\text { International } \\
\text { average }\end{array}$ & 72 & 77 & 82 & 78 & 47 \\
\hline
\end{tabular}

In all the 20 topics that were assessed across the four content domains, there were higher percentages of grade 8 students from Ghana whose teachers felt "very well prepared" to teach the topics in the content areas of the TIMSS assessment tests. As shown in Table 6, the percentages recorded by teachers in Ghana who felt "very well prepared" were higher than the international averages for all the four content areas. Unfortunately, the teachers' level of preparedness was not reflected in their students' achievement as compared to countries like Finland and Singapore.

\section{Confidence in Teaching Science}

Teacher confidence is one construct that is widely accepted by educators as having effect on how teachers teach. Science teachers who lack confidence tend to avoid teaching science and when confronted with no option but to teach science, they at best teach a version of science that more closely resembles such subjects as language and social studies (Appleton, 2008). The TIMSS 2011 report sought to find science teachers confidence in teaching science in two unique ways. The first approach was by asking teachers whether they were "very confident" or "somewhat confident" in teaching science. The report compared teachers' confidence level against the average achievement of their students. Table 7 shows data for Ghana, Tunisia, Morocco, Finland and Singapore on those scores.

Table 7. Percentage of Grade 8 Students Whose Teachers Felt Confidence in Teaching Science

\begin{tabular}{lcccc}
\hline Country & \multicolumn{2}{c}{ Very Confident } & \multicolumn{2}{c}{ Somewhat Confident } \\
\cline { 2 - 5 } & \% students & $\begin{array}{c}\text { Average } \\
\text { achievement }\end{array}$ & \% students & $\begin{array}{c}\text { Average } \\
\text { achievement }\end{array}$ \\
\hline Ghana & 95 & 307 & 5 & 290 \\
Morocco & 60 & 379 & 40 & 372 \\
Tunisia & 74 & 440 & 26 & 434 \\
Finland & 56 & 554 & 44 & 549 \\
Singapore & 60 & 595 & 40 & 583 \\
International Average & 73 & 497 & 27 & 467 \\
\hline
\end{tabular}

Table 7 shows that majority of grade 8 students in Ghana (95\%) were taught by teachers who were "Very Confident" in teaching science. This percentage was again higher than the international average (73\%) and most of the participating countries. Only a small minority of Ghanaian students (5\%) were taught by teachers who were "Somewhat Confidence" in teaching science. Table 8 provides further information about the components of the Confidence in Teaching Science scale by showing the percentage of students whose teachers reported feeling "very confident" in using each of the five instructional strategies. Teachers of the participating students were asked to indicate how confident they felt about answering students' questions about science; explaining science principles or concepts by doing science experiments; providing challenging tasks for capable students; adapting their teaching to engage students' interest; and helping students appreciate the value of learning science. Table 8 summarizes Ghana and the selected countries' data on teachers who felt very confident in doing the aspects listed above.

Again, there was high number of students whose teachers scored high on the components of confidence in teaching 
science scale in Ghana. The percentage of students whose teachers felt very confident in the component areas in Ghana was higher than the international average in all the areas. Science teachers of grade 8 students in Ghana felt very confident to answer students' questions about science as well as explain science concepts or principles through science experiments to students. They provided challenging tasks for capable students, adapted their teaching to engage students and were confident to help students appreciate the value of learning science. What is puzzling is that despite teachers' purported self-confidence in teaching science content and responding to students' questions it did not reflect in students' achievement on the TIMSS assessment. Surprisingly, Ghana could not even attain the Low International Benchmark of 400.

Table 8. Score of Teachers on the Component of Confidence Scale as a Percentage of Their Students

\begin{tabular}{lcclcc}
\hline Country & $\begin{array}{l}\text { Answer student } \\
\text { questions about } \\
\text { science }\end{array}$ & $\begin{array}{l}\text { Explain science } \\
\text { concepts or } \\
\text { principles by } \\
\text { doing science } \\
\text { experiments }\end{array}$ & $\begin{array}{l}\text { Provide } \\
\text { challenging } \\
\text { tasks for } \\
\text { capable } \\
\text { students }\end{array}$ & $\begin{array}{l}\text { Adapt teaching } \\
\text { to engage } \\
\text { student interests }\end{array}$ & $\begin{array}{l}\text { Help } \\
\text { students } \\
\text { appreciate } \\
\text { the value of } \\
\text { learning } \\
\text { science }\end{array}$ \\
\hline Finland & 70 & 66 & 47 & 40 & 51 \\
Ghana & 97 & 82 & 66 & 92 & 96 \\
Morocco & 67 & 64 & 43 & 59 & 64 \\
$\begin{array}{l}\text { Tunisia } \\
\text { Singapore }\end{array}$ & 82 & 87 & 40 & 63 & 72 \\
$\begin{array}{l}\text { International } \\
\text { average }\end{array}$ & 80 & 69 & 49 & 47 & 51 \\
\hline
\end{tabular}

\section{Teacher Career Satisfaction}

Career satisfaction is a pleasurable condition of a positive emotional state which results from one's own appraisal of his or her job experiences (Locke, 1976). Career satisfaction has the tendency of keeping professionals in their profession. TIMSS 2011 report therefore sought to find out teachers' career satisfaction. The report sought to find out how satisfied teachers were with their profession; how much they were satisfied as a teacher in their schools; their enthusiasm level as compared to when they started teaching; how important they felt teaching was; whether they plan continuing as a teacher for a long time and whether they were frustrated as teachers. The report grouped teachers' responses into three categories: satisfied, somewhat satisfied and less than satisfied. Table 9 shows data from Ghana and selected countries on the career satisfaction of their grade 8 science teachers and the average achievement of their students in science.

Table 9. Percentage of Grade 8 Students Whose Teachers were Satisfied with Their Profession and Students Average Achievement in Science

\begin{tabular}{lrrrrrr}
\hline Country & \multicolumn{2}{c}{ Satisfied } & \multicolumn{2}{c}{ Somewhat Satisfied } & \multicolumn{2}{c}{ Less Than Satisfied } \\
\cline { 2 - 7 } & $\begin{array}{l}\text { \% of } \\
\text { students }\end{array}$ & $\begin{array}{l}\text { Average } \\
\text { achievement }\end{array}$ & $\begin{array}{l}\text { \% of } \\
\text { students }\end{array}$ & $\begin{array}{l}\text { Average } \\
\text { achievement }\end{array}$ & $\begin{array}{l}\text { \% of } \\
\text { students }\end{array}$ & $\begin{array}{l}\text { Average } \\
\text { achievement }\end{array}$ \\
\hline Finland & 42 & 553 & 49 & 551 & 10 & 552 \\
Ghana & 35 & 307 & 55 & 307 & 10 & 299 \\
Morocco & 39 & 380 & 49 & 374 & 12 & 377 \\
Tunisia & 49 & 438 & 46 & 441 & 5 & 420 \\
Singapore & 28 & 592 & 51 & 592 & 13 & 576 \\
International & 47 & 481 & 45 & 474 & 8 & 473 \\
average & & & & & & \\
\hline
\end{tabular}

The data in Table 6 show mixed results with regards to teachers' career satisfaction and their students' achievement. Though Singapore had a lower percentage (28\%) of its students being taught by teachers who were satisfied with their career, they had high student achievement as compared to Ghana who had relatively high teachers (35\%) who were satisfied with their job. Only about $10 \%$ of Ghanaian students were taught by teachers who were "Less Than Satisfied". This gives an indication that, Ghanaian students were taught by teachers who were relatively content with their teaching profession yet the students' achievement in the TIMSS assessment was the poorest. 


\section{Discussion}

The TIMSS 2011 report seems to portray a high correlation between students' achievement and teachers' qualifications. According to Darling-Hammond (2004), students achievement were strongly related to teachers with strong academic qualification with the TIMSS 2011 report confirming most of the findings in the literature on teacher academic preparations. Teachers who have acquired sufficient academic preparation are seen to be competent and produce larger student achievement gains (Darling-Hammond, 2000; McDermott \& Shaffer, 2000; Orleans, 2007).

From the results obtained, the countries that had their students achieving higher are taught by teachers with higher academic qualifications, i.e. postgraduate university degree and bachelor's degrees respectively, for instance, Finland and Singapore. In Ghana, majority of teachers for JHS, under which grade eight falls, are diplomates from Colleges of Education. As described previously, these pre-service teachers are admitted into these colleges after completing high school and go on to become teachers after they have completed a three-year education program. It presupposes that content knowledge and pedagogical content knowledge acquired by diplomates of Colleges of Education is below what is acquired by teachers with postgraduate and bachelor degrees. According to Darling-Hammond (2004), the lack of qualified teachers to teach students who can compete adequately in an increasingly competitive world place constitutes a major educational inequity. It stands to reason that if teacher certification matters, then Ghana's consistently poor performance in TIMSS assessment is probably due to the quality of teachers. As a result, there may be a need to review what the minimum qualification should be for an individual to become a teacher and the number of years required for a person to be trained to join the teaching profession.

There is no argument with regards to the effect of teacher professional development on the effectiveness of their teaching as well as its impacts on student achievement. Research suggests that teachers' professional development correlates strongly with student achievement (Darling-Hammond, Wei, Andree, Richardson, \& Orphanos, 2009; Yoon, Duncan, Lee, Scarloss, \& Shapley, 2007). The art of teaching and instruction is very dynamic and thus for teachers to keep up to date with the new trends they need regular professional development in pedagogy and instructional techniques. The overall professional development participation of grade 8 science teachers in Ghana seemed to be very encouraging and commendable. However, this was not reflected in the students' achievement. The role of a teacher is to impart and guide his students to acquire and develop the needed knowledge. The teacher's knowledge is not for him to keep but to be imparted to the students. Therefore having more professional development in science content area which does not appear to impact on the 'the how to' impart the gained knowledge to students is problematic.

The data presented in Table 6 about teachers' preparedness to teach the science topics indicate that Ghana had percentages which were higher than the international averages as well as some of the top ranking countries although Ghana ranked the least country in terms of the achievement rankings. This presents issues that need further critique. Could it be that the Ghanaian teachers rated themselves too highly in terms of their preparedness to teach these topics? If not so, how come their students ranked the least when it came to their achievement? Or is it a case of there being no correlation between teacher preparedness to teach and student achievement? Again, could it be that teachers feel they are very well prepared to teach but their students are not learning and thus the poor achievement of the students? Tairab (2010) asserted that content knowledge of science is obviously fundamental to being able to impact students learning. Thus, there should be a reflection in student achievement if a teacher claims to be very well prepared to teach a particular topic. Although the data from TIMSS 2011 indicate that most of the students whose teachers felt very well prepared to teach the TIMSS topics had higher achievement scores, Ghana's data seem to be the opposite.

Teachers in Ghana felt very confident in teaching science with 95\% of grade 8 students being taught by teachers who felt confident. The percentage of students being taught by teachers who felt very confident to teach science was higher than the international average and higher than most of the participating countries. However, the confidence level of the teachers in Ghana did not reflect in the achievement of their students in the TIMSS assessment. Ghana had the lowest average achievement for students whose teachers felt very confident to teach science. Moreover, the average achievement of the grade 8 science students in Ghana was lower (306) than the international average (497). This seemed to go contrary to literature as well as the findings of the TIMSS report with regards to other countries. It could be seen in Table 7 and the TIMSS report that countries that did not have large percentage of their students being taught by teachers who felt as confident as Ghanaian teachers were still able to outperform students in Ghana who had confident teachers. For instance, both Finland and Singapore had fewer percentages (56\% and 60\%) of students who had teachers who felt confident in teaching science as compared to Ghana. The percentages of Finland (56\%) and Singapore (60\%) both fell short of the international average (73\%), yet these countries' students had 
higher achievement than their Ghanaian counterparts. Does this mean that teachers in Finland and Singapore underestimated their confidence to teach content whereas teachers in Ghana overestimated their confidence? Or does it mean that the confidence of teachers has relatively less effect on student achievement? Or were there other additional factors that influenced students' achievement scores in Finland and Singapore? This incongruity in trend provides some thought provoking data.

A belief in one's abilities is a powerful tool capable of influencing a person's motivation to act, determination to succeed and to resist setbacks (Bandura, 1977). Thus, the high levels of confidence exhibited by Ghanaian teachers as reported by the TIMSS 2011 report should reflect in their teaching which consequently should be seen in the achievement of their students. This is because a teacher may likely put in less effort in the preparation and delivery of instruction and would likely give up more readily as the students struggled if he does not expect to be successful (Tschannen-Moran \& Johnson, 2011). We believe that the converse should also be true for teachers who expect to succeed and are very confident in their abilities. Such teachers should be able to be determined to help students excel even in the face of difficulties. This did not happen in Ghana as though the teachers have high beliefs in their ability it did not reflect in their students’ performance.

\section{Conclusion}

The analysis of Ghana's participation and performance in TIMSS 2011 assessment survey in the science content domain raises critical issues that need further investigation. Although it is difficult to emphatically explain the poor performance of students in Ghana in the TIMSS report, some inferences can be made from this review. Considering teacher qualification, it was observed that Ghana had majority of her grade 8 science teachers holding qualifications lower than bachelor's degree. However, considering countries like Finland and Singapore, whose students achieved higher on the TIMSS assessment, majority of their science teachers at the same grade were either bachelor's or postgraduate degree holding teachers. According to Hökkä and Eteläpelto (2014), the objective of the Finnish teacher education program is to produce highly trained professionals who are capable of conducting research, have an analytical mind and reflective in practice. Through such rigorous training and certification process, Finnish teachers are seen as professionals capable of taking education related decisions rather than implementers of decisions. The situation in Ghana seems to be the opposite where although prospective teachers are required to conduct a research into their teaching while on clinical studies, due to the inherent fragmentations in the curriculum, the relevance of the course is lost on students. According to Korthagen (2011), a realistic teacher education program should seek to integrate theory and practice as well as the integration of several academic disciplines. In the absence of a strongly coherent teacher education program, it is not too surprising that teaching does not seem to enjoy the prestige that it enjoys in countries like Finland.

Although Ghanaian teachers indicated that they have been attending professional development, its effect did not reflect on students' achievement during the TIMSS assessment. The seeming disconnect between professional development (PD) and students' achievement may be related to the general structure for organizing these PD. According to Anderson, most PD programmes are offered in a top-down model (Anderson as cited by Appleton, 2008) and Ghana is no exception. Most often, teachers are drawn from the classroom by the authorities of the education system (Ghana Education Service) and are asked to participate in a series of workshops, lectures and seminars being run by experts (Anamuah-Mensah, Mereku, \& Ampiah, 2009). The top-down approach has been found not to be effective as compared to Bell and Gilbert (1996) transformative approach which argued for a long term teacher support rather than the one-shot professional development programmes. Again, such an approach does not follow how teachers learn which is in professional learning groups and the types of knowledge needed by teachers. By adopting teacher-with-deficit model, there is the likelihood that topics covered and the modes of presentation at some of the PD are not likely to meet the needs of participants.

Cochran-Smith and Lytle (1999) identified three types of knowledge needed by teachers which are knowledge-for-practice, knowledge-in-practice, and knowledge-of practice. The third type of knowledge, knowledge-of-practice, results when teachers learn from their teaching experiences, issues concerning learning, knowledge, and theories leading to the development of local knowledge of practice. This process renders 'practice theoretical' (Britzman, 1991, p. 47) as teachers produce their own knowledge which works in their classroom situation, and may not necessarily be generalized to other situations. In view of this, it is suggested that any PD organized for teachers should enable them to take ownership of the learning process through reflecting on their practices and connecting their practices with relevant theories. It is when teachers find topics treated as being directly relevant to their practices that there is a greater chance of transfer of training to their instructional practices and 
ultimately translating to students' learning gains (Boaler, 1997). At the moment, a top-down approach does not seem likely to yield the desired effect.

While it is generally acknowledged that success in the $21^{\text {st }}$ century requires a strong technological background for all students, Ghanaian teachers appear to be behind in terms of incorporating Information, Communication, Technology (ICT) into their teaching or received training regarding the use of ICT. Comparatively, there was a lower percentage of Ghanaian students whose teachers have had professional development compared to the international average on how to incorporate information technology into the teaching of science. This is not a very good practice for a developing country which seeks to develop students who can compete internationally. Teaching and learning has moved from the medieval chalk and talk practice. The focus of education is no more just to gain knowledge that can be used in the present but the capacity to engage in lifelong learning which can be gained through self-directed and collaborative inquiry as well as encourage connectedness through communication and collaboration with peers and experts (Law \& Yuen, 2006) has become the focus of modern education. Information technology is rightfully placed to help teachers foster, inculcate and develop these traits in students. Thus, it is necessary that Ghana improve her teachers knowledge and skills in the use of information technology in their teaching especially so for science teachers. While government has been distributing laptops to various schools in the country, which is laudable, it must be noted that effective usage of these tools require teachers to have the required expertise to use them effectively to support the teaching and learning process.

Looking at Ghanaian teachers scores on the teacher preparation constructs and the overall students achievement, one would not be wrong to conclude that the science teachers whose students participated in the TIMSS assessment: 1) are of low quality, 2) had problems with self-reporting, 3) are not effective in the classroom, and 4) lack the ability to convey ideas in clear and convincing ways to create effective learning.

\section{Recommendations}

This paper looked at Ghana's performance in the science and how the nation prepares its teachers by using the TIMSS 2011 report as convenience data. The comparison data provided on teacher preparation between Ghana and the high achieving countries offer an important insight into our effort to achieve better standard in the quality of the teaching workforce. One approach to determining how to achieve quality in the teaching workforce is to study the countries that have achieved this difficult goal. It is time to hold the bull by the horn. Ghana will continue to underperform in such international assessment if the appropriate checks are not done. As noted by National Research Council (1996, p. 28) "What students learn is greatly influenced by how they are taught", it will be appropriate therefore to examine and critique the classroom instruction data, resources for teaching science, school climate etc. included in the TIMSS report to see if there were other additional factors that accounted for the variation in Ghanaian students' achievement scores and that of the other countries like Finland and Singapore. We also recommend that a study be conducted to investigate how science is taught at the Junior High School level.

\section{References}

Akiba, Motoko, LeTendre, Gerald K., \& Scribner, Jay P. (2007). Teacher quality, opportunity gap, and national achievement in 46 countries. Educational Researcher, 36(7), 369-387.

Anamuah-Mensah, J., Mereku, D. K., \& Ampiah, G. J. (2009). TIMSS 2007 Ghana Report: Findings from IEA's Trends in International Mathematics and Science Study at the Eighth Grade. Accra: Ministry of Education, Science and Sports.

Appleton, K. (2008). Developing science pedagogical content knowledge through mentoring elementary teachers. Journal of Science Teacher Education, 19(6), 523-545. http://dx.doi.org/10.1007/s10972-008-9109-4

Bandura, A. (1977). Self-efficacy: Toward a unifying theory of behavioral change. Psychological Review, 84(2), 191-215. http://dx.doi.org/10.1037/0033-295X.84.2.191

Bell, B., \& Gilbert, J. (1996). Teacher development: A model from science education. London: Falmer Press.

Darling-Hammond, L. (2000). Teacher quality and student achievement: A review of state policy evidence. Education policy analysis archives, 8(1), 1-15.

Darling-Hammond, L., Berry, B., \& Thoreson, A. (2001). Does teacher certification matter? Evaluating the evidence. Educational Evaluation \& Policy Analysis, 23(1), 57-77. 
Darling-Hammond, L., Wei, R. C., Andree, A., Richardson, N., \& Orphanos, S. (2009). State of the Profession: Study measures status of professional development. Journal of Staff Development, 30(2), 42-50.

Goldhaber, D., \& Anthony, E. (2003). Teacher quality and student achievement. Urban diversity series. New York N. Y.: Eric Clearinghouse on Urban Education.

Hendriks, M., Luyten, H., Scheerens, J., Sleegers, P., \& Steen, R. (2010). Teachers' professional development: Europe in international comparison: An analysis of teachers' professional development based on the oecd's teaching and learning international survey (TALIS).

International Association for the Evaluation of Educational Achievement [IEA]. (2012). In M. O. Martin, P. Foy \& G. M. Stanco (Eds.), TIMSS 2011 international results in science. Chestnut Hill, MA: TIMSS \& PIRLS International Study Center.

Law, N., \& Yuen, A.H.K. (2006). Pedagogy and ICT use in schools around the world: Findings from the IEA SITES 2006 study. In N. Law, W. Pelgrum \& T. Plomp (Eds.), Pedagogy and ICT use in schools around the world: Findings from the SITES 2006 study. Hong Kong: CERC, University of Hong Kong.

Locke, E.A. (1976). The nature and causes of job satisfaction. In M. D. Dunnette (Ed.), Handbook of industrial and organizational psychology (pp. 1297-1349). Chicago, IL: Rand McNally.

Ministry of Education. (2012). Pre-tertiary teacher professional development and management in Ghana: Policy framework. Accra: Ghana Education Service.

McDermott, C. L., \& Shaffer, P S. (2000). Preparing teachers to teach physics and physical science by inquiry. Physics Education, 35(6), 411-416.

National Research Council. (1996). National science education standards. Retrieved April 8, 2013, from http://www.nap.edu/readingroom/books/nses/html/notice.html

Orleans, A. V. (2007). The condition of secondary school physics education in the Philippines: Recent developments and remaining challenges for substantive improvements. The Australian educational researcher, 34(1), 33-54.

Scheerens, J. (2009). Teachers' professional development: Europe in international comparison: A secondary analysis based on the TALIS dataset. The Netherlands: University of Twente.

Tairab, H. (2010). Assessing science teachers' content knowledge and confidence in teaching science: How confident are UAE prospective elementary science teachers? International Journal of Applied Educational Studies, 7(1), 59-71.

Tschannen-Moran, M., \& Johnson, D. (2011). Exploring literacy teachers' self-efficacy beliefs: Potential sources at play. Teaching and Teacher Education, 27(4), 751-761. http://dx.doi.org/10.1016/j.tate.2010.12.005

US Department of Education. (2006). The secretary's annual report on teacher quality: A highly qualified teacher in every classroom. Washington DC: US department of Education.

Yoon, K. S., Duncan, T., Lee, S. W-Y., Scarloss, B., \& Shapley, K. L. (2007). Reviewing the evidence on how teacher professional development affects student achievement: National Center for Educational Evaluation and Regional Assistance, Institute of Education Sciences, US Department of Education. 